Олійник О. О., к.е.н., доцент (Національний університет водного господарства та природокористування, м. Рівне)

\title{
ОСОБЛИВОСТІ РЕАЛІЗАЦІЇ ВНУТРІШНЬОЇ КОРПОРАТИВНОЇ СОЦІАЛЬНОЇ ВІДПОВІДАЛЬНОСТІ В УКРАЇНІ
}

В статті досліджено складові та показники внутрішньої корпоративної соціальної відповідальності в Україні. Проаналізовано підходи до відображення в корпоративних документах соціально відповідальних принципів взаємодії з працівниками та реалізацію основних функцій управління персоналом. Розкрито сучасні інструменти комунікації керівництва з працівниками в провідних компаніях України.

Ключові слова: корпоративна соціальна відповідальність, діалог, взаємодія, персонал, управління персоналом.

Постановка проблеми. Перехід України до сталого економічного розвитку, її інтеграція до міжнародної спільноти вимагають запровадження сучасної бізнес-практики, заснованої на засадах концепції соціальної відповідальності, що дозволило б створити умови для досягнення Глобальних Цілей Сталого Розвитку. Однак на сьогодні дотримання принципів соціально відповідальної поведінки не достатньо використовується як інструмент управління персоналом та регулювання соціально-трудових відносин. Водночас в Україні високою залишається плинність кадрів, погіршуються наслідки виробничого травматизму для соціальних партнерів, значним $є$ рівень зайнятості в шкідливих умовах праці, набуває поширення заборгованість з виплати заробітної плати. Відтак виникає необхідність в дослідженні особливостей реалізації внутрішньої корпоративної соціальної відповідальності на прикладі найбільш ефективних компаній України, які імплементують соціально відповідальні принципи в свою систему менеджменту.

Аналіз останніх досліджень та публікацій. Дослідженню проблематики корпоративної соціальної відповідальності загалом та її внутрішньої складової зокрема присвячені роботи багатьох науковців, зокрема: І. Ахновської, О. Грішнової, В. Звонаря, Я. Лагути, А. Колота, О. Новікової, М. Саприкіної, І. Тарасенко та ін. Незважаючи на значну кількість наукових публікацій в цій царині, формування ефективної системи управління персоналом на засадах соціальної відповідальності широкого поширення в практичній діяльності віт- 
чизняних компаній не набуло. Відтак, дослідження особливостей розвитку внутрішньої корпоративної відповідальності з метою досягнення балансу інтересів соціальних партнерів та удосконалення регулювання соціально-трудових відносин $є$ актуальним науковим завданням.

Метою роботи є дослідження особливостей реалізації корпоративної соціальної відповідальності перед працівниками в Україні.

Виклад основного матеріалу. Корпоративна соціальна відповідальність (КСВ) як інструмент управління набуває все більшої популярності серед бізнес-спільноти України, стає частиною стратегії розвитку багатьох сучасних компаній. Сьогодні прогресивні компанії розглядають концепцію КСВ як інноваційний важіль формування стійкої конкурентоспроможності, позитивного ділового іміджу, зростаючого попиту на свою продукцію, залучення та утримання висококваліфікованих фахівців, підвищення мотивованості та лояльності працівників тощо.

Відповідно до загальновизнаних підходів корпоративна соціальна відповідальність містить внутрішню та зовнішню складові. Внутрішня корпоративна соціальна відповідальність ототожнюється 3 відповідальністю компанії перед власними працівниками. При цьому основними напрямками їі реалізації $є$ :

1) турбота про соціальну захищеність працівників;

2) професійний розвиток та навчання працівників;

3) безпека та гігієна праці;

4) мотиваційні схеми оплати;

5) створення умов відпочинку та дозвілля;

6) підтримка внутрішніх комунікацій;

7) участь працівників в прийнятті управлінських рішень;

8) допомога працівникам у кризових ситуаціях;

9) залучення та утримання працівників [1, С. 50].

Слід відмітити, що реалізація трудових практик $є$ одним з найбільш поширених елементів корпоративної соціальної відповідальності в Україні. Водночас підходи до вибору актуальних напрямів та показників виконання внутрішньої КСВ різниться залежно від виду діяльності компанії, стратегії та цілей розвитку, організаційного та нормативно-правового забезпечення КСВ, економічних можливостей тощо (табл. 1). 


\section{Таблиця 1}

Складові та показники внутрішньої корпоративної соціальної відповідальності окремих суб'єктів господарювання в Україні

\begin{tabular}{|c|c|c|}
\hline $\begin{array}{c}\text { Суб'єкт госпо- } \\
\text { дарювання }\end{array}$ & Складові внутрішньої КСВ & Показники внутрішньої КСВ \\
\hline 1 & 2 & 3 \\
\hline $\begin{array}{c}\text { Інвестиційна } \\
\text { група VOLWEST } \\
\text { GROUP }\end{array}$ & $\begin{array}{l}\text { - Кар'єрне зростання: кадровий } \\
\text { резерв, об'єктивна оцінка під час } \\
\text { атестації; } \\
\text { - професійне зростання: пільгове } \\
\text { навчання у Бізнес Академії прак- } \\
\text { тичного менеджменту, програми } \\
\text { підвищення кваліфікації, тренін- } \\
\text { ги, семінари; } \\
\text { - особистісний та духовний роз- } \\
\text { виток: відвідування мистецьких, } \\
\text { культурних та просвітницьких } \\
\text { подій; } \\
\text { - гарантія соціального базису: } \\
\text { комфортні умови праці, виплати, } \\
\text { пільги, корпоративні бонуси }\end{array}$ & $\begin{array}{l}\text { Загальна сума соціальних ви- } \\
\text { плат; кількість працівників, } \\
\text { які пройшли корпоративне } \\
\text { навчання; плинність кадрів; } \\
\text { кількість тренінгів на тему } \\
\text { КСВ }\end{array}$ \\
\hline $\begin{array}{l}\text { Корпорація } \\
\text { «ОБОЛОНь» }\end{array}$ & $\begin{array}{l}\text { - Безпека праці; } \\
\text { - гідна заробітна плата; } \\
\text { - відсутність дискримінації та рі- } \\
\text { вні права; } \\
\text { - гендерна рівність; } \\
\text { - інвестиції у професійний розви- } \\
\text { ток; } \\
\text { - визнання результатів }\end{array}$ & $\begin{array}{l}\text { Кількість працівників; розпо- } \\
\text { діл працівників за віком, стат- } \\
\text { тю, ступенем зайнятості, спе- } \\
\text { ціалізацією, підприємствами, } \\
\text { сімейними обов'язками; } \\
\text { плинність кадрів; інвестиції в } \\
\text { охорону праці; заходи з охо- } \\
\text { рони праці; кількість праців- } \\
\text { ників з особливими потреба- } \\
\text { ми; кількість нещасних випа- } \\
\text { дків; обсяг матеріальної до- } \\
\text { помоги працівникам при на- } \\
\text { родженні дітей; гендерна } \\
\text { структура керівництва; кіль- } \\
\text { кість працівників, що пройш- } \\
\text { ли професійне навчання; се- } \\
\text { редня та загальна тривалість } \\
\text { навчання; розмір середньої } \\
\text { заробітної плати; загальний } \\
\text { фонд фінансової допомого } \\
\text { працівникам; складові соціа- } \\
\text { льного пакету }\end{array}$ \\
\hline
\end{tabular}


продовження табл. 1

\begin{tabular}{|c|c|c|}
\hline 1 & 2 & 3 \\
\hline $\begin{array}{c}\text { ДП «НАЕК } \\
\text { «ЕНЕРГОАТОМ» }\end{array}$ & $\begin{array}{l}\text { - Управління персона- } \\
\text { лом; } \\
\text { - оплата праці та соціа- } \\
\text { льні гарантії; } \\
\text { - охорона праці; } \\
\text { - утримання та розвиток } \\
\text { об'єктів соціальної сфе- } \\
\text { ри; } \\
\text { - турбота про здоров'я } \\
\text { працівників; } \\
\text { - розвиток корпоративної } \\
\text { культури; } \\
\text { - розвиток персоналу }\end{array}$ & $\begin{array}{l}\text { Кількість працівників; структура за } \\
\text { категоріями, статтю, віком; витрати на } \\
\text { підготовку персоналу; витрати на со- } \\
\text { ціальні пільги; структура кошторису } \\
\text { витрат на соціальний розвиток; ви- } \\
\text { трати на утримання об'єктів житлово- } \\
\text { комунального та соціально- } \\
\text { культурного призначення; санаторно- } \\
\text { курортне лікування; фонд оплати } \\
\text { праці; витрати на охорону праці; ви- } \\
\text { робничий травматизм; навчання пра- } \\
\text { цівників з питань охорони праці; ме- } \\
\text { догляд працівників; підготовка пер- } \\
\text { соналу }\end{array}$ \\
\hline
\end{tabular}

Джерело: складено за даними [2; 3; 4].

Таким чином, невід'ємною складовою внутрішньої КСВ є питання охорони та безпеки праці, професійного розвитку працівників, оплати праці та соціальних гарантій. В той же час в прогресивних компаніях України впроваджуються інноваційні соціально відповідальні практики для працівників. Для прикладу, Медіа-група 1+1 реалізує програму «Нові вершини», яка направлена на розвиток корпоративних цінностей: відповідальність, відкритість, сміливість, любов та повага, а також розвиток таких рис характеру, як цілеспрямованість та витривалість, підкорення власних страхів та загартування духу. Працівники разом піднімаються на високі гори України й інших країн. Це чудовий тім-білдінг, який допомагає досягати спільних цілей. За 4 роки у програмі взяли участь 222 співробітника [5].

На вибір об'єктів корпоративних практик суттєвий вплив здійснюють зовнішні загрози, що стоять перед Україною. Так, компанія «Нова пошта» надає підтримку співробітникам, яких було мобілізовано до лав Збройних Сил України. Компанія повністю забезпечила їх засобами захисту, медикаментами та мобільним зв'язком для спілкування з рідними. На допомогу співробітникам було спрямовано понад 2,5 млн гривень [6].

Важливим під час організації внутрішньої корпоративної соціальної відповідальності є: визначення основних адресатів (об'єктів) відповідальності; визначення структур управління, які будуть організовувати КСВ, і відповідне наділення їх повноваженнями; визначення учасників та співучасників відповідальності; визначення бюджету на реалізацію КСВ; розроблення стратегії соціально відповідальних заходів та їі інтеграція в стратегію розвитку [7]. 
Компанії, які позиціонують себе як соціально відповідальні, мають розроблену систему цінностей, місію і бачення - ключові складові будь-якої організації. Переважно ці елементи відображаються в таких корпоративних документах, як Стратегія корпоративної соціальної відповідальності, Корпоративний кодекс, Кодекс корпоративної етики тощо. Однак, за результатами дослідження Центру «Розвиток КСВ», працівники не беруть участі у розробленні основної документації з корпоративної соціальної відповідальності: у $35 \%$ опитаних компаній співробітники не брали участі у розробленні Кодексів поведінки взагалі, а в решті компаній були залучені лише представники HR-департаментів [8].

Водночас в Україні поширюється тенденція декларування 30бов'язань у сфері корпоративної соціальної відповідальності перед окремими ключовими стейкхолдерами. Що стосується працівників, то соціально відповідальні принципи взаємодії з ними, підходи до реалізації основних функцій управління персоналом відображаються в Кадровій стратегії або HR-стратегії. Так, на підприємствах Агропромхолдингу АСТАРТА-КИїВ окрім Кодексу корпоративної етики, соціально-економічні та трудові відносини працівників регулюються такими корпоративними стандартами:

1. Кадрова політика.

2. Положення про організаційну структуру.

3. Правила внутрішнього трудового розпорядку.

4. Правила техніки безпеки та охорони праці.

5. Положення про соціальне партнерство.

6. Положення про скорочення штату або чисельності працівників та виплату вихідної допомоги, що забезпечує соціальні гарантії працівників [9].

Ще більш деталізовано реалізацію внутрішньої КСВ через корпоративні документи в ПАТ «Миронівський хлібопродукт»:

1. Кадрова політика ПАТ «Миронівський хлібопродукт».

2. Процедура підбору та адаптації персоналу.

3. Положення про оцінку професійної діяльності персоналу.

4. Положення про оплату праці (для кожного підприємства).

5. Положення про преміювання персоналу (для кожного підприємства).

6. Положення про дошку пошани.

7. Положення про присвоєння звання «Почесний пенсіонер».

8. Положення про наставництво.

9. Положення про присвоєння винагород.

10. Положення про роботу з кадровим резервом.

11. Положення про навчання співробітників компанії. 
12. Положення про навчання дітей співробітників.

13. Положення про молодих спеціалістів.

14. Положення про облік робочого часу.

15. Положення про порядок розгляду скарг.

16. Процедури та інструкції з обліку кадрів (прийом та звільнення) [10].

Важливим елементом, що дозволяє забезпечити високу ефективність реалізації внутрішньої КСВ, $є$ постійний діалог та взаємодія між менеджментом та працівниками. Компанії в Україні використовують різноманітні канали комунікацій, які допомагають сформувати дієвий зворотній зв'язок та створюють можливості для підвищення ефективності господарської діяльності (табл. 2).

Таблиця 2

Інструменти комунікації з працівниками окремих суб'єктів господарювання в Україні

\begin{tabular}{|c|c|}
\hline $\begin{array}{c}\text { Суб'єкт } \\
\text { господарювання }\end{array}$ & Інструменти комунікації \\
\hline $\begin{array}{c}\text { ПАТ «Миронівсь- } \\
\text { кий хлібопро- } \\
\text { дукт» }\end{array}$ & $\begin{array}{l}\text { Скринька звернень } \\
\text { Сайт } \\
\text { Портал для працівників } \\
\text { Гаряча лінія Служби етичного контролю } \\
\text { Особистий прийом } \\
\text { Телефон }\end{array}$ \\
\hline $\begin{array}{l}\text { Корпорація } \\
\text { «ОБОЛОНь» }\end{array}$ & $\begin{array}{l}\text { Дослідження, опитування (щорічно/за потребою) } \\
\text { Фокус-групи (за потребою) } \\
\text { Обмін фахівцями (за потребою) } \\
\text { Співпраця з профспілкою (на постійній основі) } \\
\text { Інтранет, корпоративні ЗМІ (щоденно/щоквартально) }\end{array}$ \\
\hline $\begin{array}{c}\text { ДП «НАЕК «ЕHЕ- } \\
\text { РГОАТОМ» }\end{array}$ & $\begin{array}{l}\text { Відкритий діалог керівництва з працівниками } \\
\text { Соціальні опитування } \\
\text { Програми навчання для працівників } \\
\text { Участь працівників у проектах з розвитку територій присутнос- } \\
\text { ті } \\
\text { Участь працівників у проектах корпоративного волонтерства } \\
\text { Партнерство з навчальними закладами в рамках підготовки } \\
\text { майбутніх кадрів для АЕС }\end{array}$ \\
\hline Медіа-група 1+1 & $\begin{array}{l}\text { Сайт медіа-групи та телеканалів, портали медіа-групи } \\
\text { Прямі комунікації } \\
\text { Соціальні мережі } \\
\text { Телеканали медіа-групи } \\
\text { Публікації у ЗМІ, прес-релізи } \\
\text { Внутрішній портал, внутрішні комунікації, дайджест } \\
\text { Заходи }\end{array}$ \\
\hline
\end{tabular}

Джерело: складено за даними [3; 4; 5; 11$]$. 
Окрім регулярних опитувань, сайтів, прямих звернень та інших відомих засобів комунікації, компанії впроваджують нові підходи для налагодження діалогу з працівниками. Компанія Ernst \& Young в Україні започаткувала роботу Консультативної ради колективу як платформи для обговорення та вирішення питань щодо можливостей навчання, розвитку та обміну досвідом, оновлення внутрішніх політик та процедур, питань комфорту в офісі та ініціатив щодо поліпшення умов праці. Рада складається з представників кожного напряму послуг пропорційно до кількості людей у відділі. Місія ради не лише вирішувати проблеми, озвучені працівниками, але й залучати працівників у процес прийняття управлінських рішень у компанії. Рада реагує на всі ініціативи, але тільки ті з них, що були підтримані значною кількістю голосів, реалізують. Так, у 2016 році, було успішно реалізовано п'ятнадцять ініціатив, що додали більше комфорту та креативу до офісних буднів [12].

Висновки. Результати проведеного дослідження дозволяють зробити висновки, що реалізація внутрішньої корпоративної соціальної відповідальності більше притаманна великим компаніям України. При цьому соціально відповідальні трудові практики суттєво різняться залежно від сфери господарювання. Водночас необхідним $\epsilon$ поширення та імплементація принципів концепції КСВ в діяльність малого та середнього бізнесу, оскільки це $є$ дієвим управлінським інструментом в системі управління персоналом та дозволяє компанії:

- здійснювати превентивний вплив на наявні на потенційні ризики у соціально-трудових відносинах, оптимізувати їхні наслідки для соціальних партнерів;

- сформувати та розвивати корпоративну культуру;

- сформувати позитивний імідж успішного роботодавця;

- підвищити вмотивованість та лояльність працівників;

- покращити якість трудового життя тощо.

1. Грішнова О. А., Міщук Г. Ю., Олійник О. О. Соціальна відповідальність у трудових відносинах: теорія, практика, регулювання ризиків : монографія. Рівне : НУВГП, 2014. 216 с. 2. Звіт з корпоративної соціальної відповідальності Інвестиційної групи VOLWEST GROUP за 2016 рік / IГ VOLWEST GROUP. URL: http://volwestgroup.com/wpontent/uploads/2017/04/Zvit_KSV_2016_pdf.pdf (дата звернення : 05.10.2018). 3. Звіт про сталий розвиток корпорації «ОБОЛОНь» за 2014 рік. / Корпорація «ОБОЛОНЬ». URL: http://obolon.ua/ua/corporate-responsibility/socialreporting (дата звернення : 05.10.2018). 4. Нефінансовий звіт за 2016 ДП «HAEK «ЕНЕРГОАТОМ» / ДП «НАЕК «ЕНЕРГОАТОM». URL: http://www.energoatom.kiev.ua/ua/actvts/sustainable_development/non_fina ncial_reporting/52979-nefnansoviyi_zvt_naek_energoatom_za_rk/ (дата 
звернення : 05.10.2018). 5. Звіт з корпоративної соціальної відповідальності 1+1 медіа / Медіа група 1+1. URL: https://media.1plus1.ua/storage/CSRreport-2016-1516269221384.pdf (дата звернення : 05.10.2018). 6. Соціальний звіт компанії «Нова пошта» за 2015 рік / Соціально відповідальний бізнес. URL: http://svb.ua/sites/default/files/social_report_0.pdf (дата звернення : 05.10.2018). 7. Лагута Я. М. Внутрішня корпоративна соціальна відповідальність підприємств: основні теоретичні та практичні аспекти. Східна $\epsilon_{B-}$ ропа: економіка, бізнес та управління. Електонний науково-практичний журнал. 2017. № 3 (08). С. 153-157. 8. Социальная ответственность: кадры решают все / Центр «Розвиток KCB» URL: http://csr-ukraine.org/wpcontent/uploads/2014/04/Guide_1.pdf (дата звернення : 05.10.2018). 9. Звіт зі сталого розвитку за 2016 рік Агропромхолдингу АСТАРТА-КИїВ / Агропромхолдинг АСТАРТА-КИїВ.

URL: http://www.astartaholding.com/modules/pages/upload/file/2017/astarta_zvit _web.pdf (дата звернення : 05.10.2018). 10. Кадрова політика ПАТ «Миронівський хлібопродукт» / Агропромхолдинг ПАТ «Миронівський хлібопродукт». URL: https://www.mhp.com.ua/library/file/kadrovaja-ukr.PDF (дата звернення : 05.10.2018). 11. План взаємодії із зацікавленими сторонами ПАТ «Миронівський хлібопродукт» / ПАТ «Миронівський хлібопродукт». URL: $\quad$ https://www.mhp.com.ua/uk/responsibility/communication/planvzajemodii-iz-zatsikavlenimi-storonami (дата звернення : 05.10.2018). 12. Звіт про діяльність компанії EY в Україні в галузі сталого розвитку за 2015-2016 роки «Удосконалюючи бізнес, змінюємо світ на краще» / Компанія EY в Україні. URL: https://www.ey.com/ua/uk/about-us/corporateresponsibility/ey-ukraine-sustainability-report-2015-2016\#section5 (дата звернення : 05.10.2018).

\section{REFERENCES :}

1. Hrishnova 0. A., Mishchuk H. Yu., Oliinyk 0. 0. Sotsialna vidpovidalnist u trudovykh vidnosynakh: teoriia, praktyka, rehuliuvannia ryzykiv : monohrafiia. Rivne : NUVHP, 2014. 216 s. 2. Zvit z korporatyvnoi sotsialnoi vidpovidalnosti Investytsiinoi hrupy VOLWEST GROUP za 2016 rik / IH VOLWEST GROUP. URL: http://volwestgroup.com/wp-ontent/uploads/2017/04/Zvit_KSV_2016_pdf.pdf (data zvernennia : 05.10 .2018 ). 3. Zvit pro stalyi rozvytok korporatsii «OBOLON» za 2014 rik. / Korporatsiia «OBOLON» / Sotsialna zvitnist. URL: http://obolon.ua/ua/corporate-responsibility/social-reporting (data zvernennia : 05.10.2018). 4. Nefinansovyi zvit za 2016 DP «NAEK «ENERHOATOM» / DP «NAEK UENERHOATOM». URL: http://www.energoatom.kiev.ua/ua/actvts/sustainable_development/non_fina ncial_reporting/52979-nefnansoviyi_zvt_naek_energoatom_za_rk/ (data zvernennia : 05.10.2018). 5. Zvit z korporatyvnoi sotsialnoi vidpovidalnosti 1+1 media / Media hrupa 1+1. URL: https://media.1plus1.ua/storage/CSR-report2016-1516269221384.pdf (data zvernennia : 05.10.2018). 6. Sotsialnyi zvit kompanii «Nova poshta» za 2015 rik / Sotsialno vidpovidalnyi biznes. URL: 
http://svb.ua/sites/default/files/social_report_0.pdf (data zvernennia : 05.10.2018). 7. Lahuta Ya. M. Vnutrishnia korporatyvna sotsialna vidpovidalnist pidpryiemstv: osnovni teoretychni ta praktychni aspekty. Skhidna Yevropa: ekonomika, biznes ta upravlinnia. Elektonnyi naukovo-praktychnyi zhurnal. 2017. № 3 (08). S. 153-157. 8. Sotsyalnaia otvetstvennost: kadrb reshaiut vse / Tsentr «Rozvytok KSV» URL: http://csr-ukraine.org/wpcontent/uploads/2014/04/Guide_1.pdf (data zvernennia : 05.10.2018). 9. Zvit zi staloho rozvytku za 2016 rik Ahropromkholdynhu ASTARTA-KYIV / Ahropromkholdynh ASTARTA-KYIV. URL: http://www.astartaholding.com/modules/pages/upload/file/2017/astarta_zvit _web.pdf (data zvernennia : 05.10.2018). 10. Kadrova polityka PAT «Myronivskyi khliboprodukt» / Ahropromkholdynh PAT «Myronivskyi khliboprodukt». URL: https://www.mhp.com.ua/library/file/kadrovaja-ukr.PDF (data zvernennia : 05.10.2018). 11. Plan vzaiemodii iz zatsikavlenymy storonamy PAT «Myronivskyi khliboprodukt» / PAT «Myronivskyi khliboprodukt». URL: https://www.mhp.com.ua/uk/responsibility/communication/plan-vzajemodiiiz-zatsikavlenimi-storonami (data zvernennia : 05.10.2018). 12. Zvit pro diialnist kompanii EY v Ukraini v haluzi staloho rozvytku za 2015-2016 roky «Udoskonaliuiuchy biznes, zminiuiemo svit na krashche» / Kompaniia EY v Ukraini. URL: https://www.ey.com/ua/uk/about-us/corporateresponsibility/ey-ukraine-sustainability-report-2015-2016\#section5 (data zvernennia : 05.10.2018).

Рецензент: д.е.н., професор Міщук Г. Ю. (НУВГП)

Oliinyk 0. 0., Candidate of Economics (Ph.D.), Associated Professor (National University of Water and Environmental Engineering, Rivne)

\section{PECULIARITIES OF IMPLEMENTING INTERNAL CORPORATE SOCIAL RESPONSIBILITY IN UKRAINE}

The article examines the components and indicators of internal corporate social responsibility implemented by Ukrainian companies. The author substantiated that the choice of CSR employment practices frequently depends on the type of company's activity, its mission and strategic goals, organisational and regulatory provision of CSR, as well as financial opportunities. At the same time, the issue of occupational safety and health, professional development of employees, wages and social safety net is an integral part of internal CSR. The paper analyses approaches to the reflection of socially responsible principles of interaction with employees and recognition of the basic functions of HR management in corporate documents. The researcher determined that the companies declare their CSR 
commitments to employees in such documents as the Corporate Social Responsibility Strategy, the Corporate Code of Conduct, the Code of Corporate Ethics, etc. In addition to these documents, corporate standards with regard to individual functions of HR management also regulate social, economic and employment relations of employees. The author substantiated that interaction between management and employees is an important element that ensures high efficiency of internal CSR implementation. The article also investigated the main channels of communication, which are used by the companies in Ukraine to establish a permanent dialogue with employees. The research determined that regular polls, websites, direct communications, social networks, corporate mass media and other means of communication help to form effective feedback and create opportunities for increasing the efficiency of economic activity. Keywords: corporate social responsibility, dialogue, interaction, personnel, HR.

Олейник Е. А., к.э.н., доцент (Национальный университет водного хозяйства и природопользования, г. Ровно)

\section{ОСОБЕННОСТИ РЕАЛИЗАЦИИ ВНУТРЕННЕЙ КОРПОРАТИВНОЙ СОЦИАЛЬНОЙ ОТВЕТСТВЕННОСТИ В УКРАИНЕ}

В статье исследованы составляющие и показатели внутренней корпоративной социальной ответственности в Украине. Проанализированы подходы к отражению в корпоративных документах социально ответственных принципов взаимодействия с работниками и реализации основных функций управления персоналом. Раскрыты современные инструменты коммуникации руководства с работниками в ведущих компаниях Украины.

Ключевые слова: корпоративная социальная ответственность, диалог, взаимодействие, персонал, управление персоналом. 